Article

\title{
A Colorimetric pH Sensor Based on Clitoria sp and Brassica sp for Monitoring of Food Spoilage Using Chromametry
}

\author{
Noor Azizah Ahmad ${ }^{1,2}$, Lee Yook Heng ${ }^{1}$, Faridah Salam ${ }^{2}$, Mohd Hazani Mat Zaid ${ }^{1}$ and \\ Sharina Abu Hanifah 1,* \\ 1 Center for Advanced Materials and Renewable Resources, Faculty of Science and Technology, \\ Universiti Kebangsaan Malaysia, Bangi 43600, Selangor, Malaysia; noorazizah.ahmad@gmail.com (N.A.A.); \\ leeyookheng@yahoo.co.uk (L.Y.H.); zani@ukm.edu.my (M.H.M.Z.) \\ 2 Malaysian Agricultural Research Development Institute, Serdang 43400, Selangor, Malaysia; \\ fafaridahs@mardi.gov.my \\ * Correspondence: sharina@ukm.edu.my
}

Received: 18 September 2019; Accepted: 21 October 2019; Published: 5 November 2019

\begin{abstract}
A developed colorimetric $\mathrm{pH}$ sensor film based on edible materials for real-time monitoring of food freshness is described. The mixed natural dyes from edible plants Clitoria sp and Brassica $\mathrm{sp}$ were extracted and incorporated into l-carrageenan film as a colorimetric $\mathrm{pH}$ sensor film for monitoring food spoilage and its freshness. The color changes of the developed colorimetric sensor film were measured with chromametry and UV-vis spectroscopy, respectively. Experimental results show that colorimetric $\mathrm{pH}$ sensor film demonstrated statistically significant differences $(\mathrm{p}<0.05)$ between CIE-L*a*b* coordinates color system indicated that the developed colorimetric sensor film was able to give a gradual change in color over a wide $\mathrm{pH}$ range. The color of the colorimetric sensor film also changes discretely and linearly with factors that contribute to food spoilage using shrimp and durian samples. Moreover, the developed colorimetric $\mathrm{pH}$ sensor film has the potential to be used as a safe, non-destructive testing and also a flexibly visual method for direct assessment of food freshness indicator during storage.
\end{abstract}

Keywords: colorimetric $\mathrm{pH}$ sensor film; mixed natural dye; l-carrageenan; food spoilage

\section{Introduction}

Food spoilage have a profound impact on security, environment, quality and food safety. In some cases, many foods item were discarded because of perishable before sold. These losses have a major environmental and direct economic impact especially on retailers, food services and consumers if it is not addressed promptly [1,2]. A reduction in shelf life of foods as a result of microbial contamination and an increase in the risk of food-borne illness are driving forces for innovative means to monitor freshness of the foods while enhancing its safety [3]. Therefore, established technique such as gas-chromatography [4], mass spectroscopy [5] infrared spectroscopy [6] magnetic resonance imaging [7] and microbiological analysis [8] has become the method of choice to evaluate the food quality. However, these techniques are bulky, requires bench top instrumentation, costly and time-consuming [9]. Alternatively, a new concept have been developed through the fabrication of intelligent packaging in the form of a food spoilage indicator to monitor quality status.

Real time chromametry measurement based on CIELab system offered a great potential as a measurement tool to assessing food security and often used in the food industry [10,11]. This system is based on a "standard eye" with filters for three primary colors comprising red, green and blue and also has been suggested by Commission International de l'Eclairage (CIE) due to its reliable system for 
description of color [12]. However, knowledge of quality-indicating metabolites is needed as a main prerequisite in the development of food spoilage indicator [13] particularly for real time chromametry measurement. Typically, these metabolites are substances responsible for food color change produced by bacteria, mold and yeast during their deterioration such as carbon dioxide, sulfur dioxide, ammonia, amine, organic acids, ethanol, toxins or enzymes [14]. Besides, it also can be used as a food marker for commercial freshness indicators [15]. Therefore, several natural and synthetic compounds reported offers particularly useful and inexpensive metabolites indicator that potentially providing direct information on product quality within food product [16].

Previously, some scientists have identified a few synthetic compounds that capable to response through color change in the presence of target volatile compounds such as bromocresol purple [17], methyl red [18], bromophenol blue [19] and chlorophenol red [20]. However, in food applications, these synthetic compounds are unfitted to be used as sensor for food freshness determination because they are harmful to the environment and are associated with allergic, toxic and other harmful reactions [21]. Hence, the pigments extracted from natural resources are expected to be safe and secure in sensor application as it is low toxicity, renewable, convenience and free from contamination [22].

Anthocyanins typically can be found primarily in flower petals, leaves and fruits offering an alternative to synthetic food colorants which unfortunately is undesirable due to health concerns [23]. These types of food colorants, also known as bio-colorants, can be found in some tropical plants such as Nees (Strobilanthes cusia), Red potatoes (Solanum tuberosum), True indigo (Indigofera tinctoria), Marigold (Tagetes erecta) and Turmeric (Curcuma longa) [24,25]. Among these, anthocyanins from Butterfly pea (Clitoria sp) and red cabbage (Brassica sp) are the few natural food colorant, used widely around the world ranging from drink dye to food due to its fascinating deep blue and red color [26,27]. Previous studies showed that both plants also act as naturally-derived $\mathrm{pH}$ dyes for colorimetric bio-indicator and perceived as lower risk to the consumer. In addition, both plants have been successfully used in the development of colorimetric sensor as they provide significant changes on the color spectra of the films at a certain level of food freshness [28,29].

In order to natural dye indicators to work well, they need entrapment matrices to achieve uniform immobilization to stabilize its function. Previously, variety of entrapment matrices have been extensively used for immobilization of anthocyanin based material such as glass beads [30], hydrogel polymeric [31] membranes [32], sol-gel matrices [33] and even cassava starch [28]. Carrageenan is composed of linear polysaccharide chains, with sulfate half-esters attached to the sugar unit has wider industrial applications, especially as food grade materials is one of the most widely used immobilization matrix [34].

Currently, there is very little investigation on the use of mixed natural dyes for the fabrication of colorimetric sensor for the direct and in-contact food quality assessment. Thus, the idea to use a mixture of anthocyanin extracted from two edible plants and incorporated them into one single platform matrices is expected to have benefit for detecting of food freshness because of its non-toxic nature. Additionally, mixed-dye indicators could be potentially broader the range of color change as compared with a single indicator, thus enabling a wider $\mathrm{pH}$ range response. Therefore, in this study, the development and characterization of colorimetric $\mathrm{pH}$ sensor film for food spoilage assessment based composite film was performed with a mixed natural dye containing an extract from the edible parts of the Clitoria sp and Brassica sp plants and ı-carrageenan film. Anthocyanins contain in Clitoria sp and Brassica sp is expected to exhibit a reversible change in molecular structure as the $\mathrm{pH}$ of solutions change from acidic to basic. To identify the color change in response to $\mathrm{pH}$, a statistical evaluation was performed to correlate the color response of the sensor film $\left(\mathrm{L}^{*}, \mathrm{a}^{*}, \mathrm{~b}^{*}\right.$ and $\left.\mathrm{C}^{*}\right)$ with the measured $\mathrm{pH}$ values of the samples. 


\section{Material and Methods}

\subsection{Materials and Reagents}

The Clitoria sp flowers were plucked from the MARDI, Serdang planting area. The Brassica sp was bought from the local market at Kajang, Malaysia. I-carrageenan was purchased from J\&K (China; degree of deacetylation, 18-20\%; molecular weight, 100,000-300,000). Three types of buffer solutions were used to test the color schemes of the colorimetric sensor film consist of hydrochloric acid-potassium chloride buffer ( $\mathrm{pH}$ 1-2), citrate buffer $(\mathrm{pH} 3-8)$ and carbonate-bicarbonate buffer ( $\mathrm{pH}$ 9-10). In the case of $\mathrm{pH} 11-13$, the combination of hydrochloric acid-sodium hydroxide was used and their $\mathrm{pH}$ values were measured using a digital $\mathrm{pH}$ meter (CyberScan $\mathrm{pH}$ 510, EUTECH). The $\mathrm{pH}$ values of shrimp flesh and durian pulp are determined in triplicate on the homogenate sample with distilled water using a digital $\mathrm{pH}$ meter. All solutions were prepared using ultrapure water obtained from a Millipore purification system.

\subsection{Extraction of Anthocyanins from Clitoria sp and Brassica sp}

To extract anthocyanins from Clitoria sp, aqueous extraction method was done according to the procedure as described in Kungsuwan et al. [35] with some modification. Firstly, $40 \mathrm{~g}$ of the petals were dissolved in $100 \mathrm{~mL}$ distilled water about $30 \mathrm{~min}$ and grind them in a blender for $30 \mathrm{~s}$.

While the extraction method for Brassica sp has been carried out using the method proposed by Devarayan \& Kim [36] with some modification. The sample was extracted by taking $50 \mathrm{~g}$ of grinding Brassica sp and soaked in $100 \mathrm{~mL}$ of $80 \%$ ethanol. After that, it kept under constant stirring using shaker (150 rpm, $12 \mathrm{~h}$ ) at room temperature in the dark condition.

Then, both samples were filtered separately through two layers of muslin cloths to remove any coarse particles. Each of the filtrates samples was centrifuged (Heraeus \# 7590 centrifuge) at $4293.12 \mathrm{~g}$ for $10 \mathrm{~min}$ to remove the fine suspended particles. Subsequently, $100 \mathrm{~mL}$ of each clear extracts were concentrated under vacuum using Buchi, Rotavapor R-3 at $50{ }^{\circ} \mathrm{C}$ to filtrate volume of about $20 \mathrm{~mL}$. Finally, the concentration of anthocyanin in the extracted solution was determined by Liquid Chromatography Mass Spectrometry of Quadrupole Time-Of-Flight (LCMS-QTOF-MS/MS). The respective concentrated extracts samples consist of Clitoria sp and Brassica sp were stored at $-19^{\circ} \mathrm{C}$ until ready to use.

\subsection{Fabrication of Colorimetric $p H$ Sensor Film}

The film for colorimetric $\mathrm{pH}$ sensor was prepared by slowly dissolved $\mathrm{t}$-carrageenan in distilled water under continuous stirring with a magnetic stirrer until the powder was completely dissolved. A concentrated dye extract containing anthocyanin from the Clitoria sp and Brassica sp extract mixture was homogenized in filmogenic suspension with ratio of 1:1. The obtained solutions were then poured into a series of Petri dishes. To control the film thickness, the quantity of each film-forming solution is always fixed. Drying is done by using an oven at a temperature of $37 \pm 1{ }^{\circ} \mathrm{C}$ for $18-24 \mathrm{~h}$. The films obtained from the plate were removed and stored in desiccators. Response optimization of the three raw materials such as $\mathrm{CaCl}_{2}$ concentration, mixed natural dye concentration and the amount of matrix polymer ı-carrageenan were carried out after the fabrication of colorimetric sensor film. The preparation method of control $\mathrm{\iota}$-carrageenan film is similar to colorimetric $\mathrm{pH}$ sensor film but without added of $\mathrm{CaCl}_{2}$ and mixed natural dye.

\subsection{Film Characterization for Colorimetric $\mathrm{pH}$ Sensor}

\subsubsection{Spectroscopy Analysis}

The UV-vis spectra of single extracts, mixed natural dye and colorimetric sensor film in the different pH buffer solutions ( $\mathrm{pH}$ 1-13) were analyzed using a UV-Vis Spectrophotometer (Varian Carry 100) in the range of $380-800 \mathrm{~nm}$. While Fourier transform infrared (FTIR) spectra were recorded by Perkin-Elmer 
spectrophotometer (Spectrum 400 Model) with resolutions of $4 \mathrm{~cm}^{-1}$ in the wavenumber range of $4000-650 \mathrm{~cm}^{-1}$. All the spectra presented were obtained in transmission mode.

\subsubsection{Color Measurements}

The color value of the sensor was measured with a chromameter (Konica Minolta, Chroma Meter CR 400, Tokyo, Japan). The values of the rectangular coordinates $\left(L^{*}, a^{*}, b^{*}\right)$, where $\left(L^{*}\right)$ is lightness, $a^{*}$ is the degree of redness or greenness and $b^{*}$ is the degree of yellowness or blueness were recorded to calculate the perceptual correlate chroma value, $C^{*}$ (Equation (1)) [37] and total color differences, $\Delta \mathrm{E}^{*}$ (Equation (2)) [38] by using equation below:

$$
\begin{gathered}
\mathrm{C}^{*}=\left(\mathrm{a}^{* 2}+\mathrm{b}^{* 2}\right)^{1 / 2} \mathrm{~L} \\
\Delta \mathrm{E}^{*}=\left[\left(\Delta \mathrm{L}^{*}\right)^{2}+\left(\Delta \mathrm{a}^{*}\right)^{2}+\left(\Delta \mathrm{b}^{*}\right)^{2}\right]^{1 / 2}(2)
\end{gathered}
$$

where: $\Delta \mathrm{L}^{*}=\mathrm{L}^{*}-\mathrm{L} 0^{*} ; \Delta \mathrm{a}^{*}=\mathrm{a}^{*}-\mathrm{a} 0^{*} ; \Delta \mathrm{b}^{*}=\mathrm{b}^{*}-\mathrm{b} 0^{*}\left(\mathrm{~L} 0^{*}, \mathrm{a} 0^{*}\right.$ and $\mathrm{b} 0^{*}$ are the color parameters of the reference standard using a white standard plate provided by Minolta with color coordinates of $\mathrm{L}_{\text {standard }}=94.79, \mathrm{a}^{*}$ standard $=-0.42$ and $\mathrm{b}^{*}$ standard $=3.44$.

\subsubsection{Repeatability and Reproducibility Study}

Repeatability and reproducibility analysis was performed by referring Zhang et al. with modification [32]. The sensing film was immersed in a $\mathrm{pH} 4$ buffer solutions then analyzed in the range of 380-800 nm of wavelength. These steps were repeated 5 times using different film and buffers for repeatability but the similar film and buffers were used for reproducibility analysis. Then, the whole procedure was repeated for buffer solution of $\mathrm{pH} 7$ and 12. The percentage of RSD was calculated using the following Equation:

$$
\operatorname{RSD}(\%)=(\text { Standard deviation/average }) \times 100
$$

\subsection{Food Application}

\subsubsection{Sample Preparation}

The portion of shrimp was put on the polystyrene tray while polypropylene tray has been used for durian sample. To ensure a closed space, both trays were packed into packaging material of oriented nylon polyethylene (Ony/PE) with $0.10 \mathrm{~mm}$ of thickness. Then the sensor film was placed at the headspace of each package before sealing properly. The shrimps and durian samples were stored at ambient temperature $\left(28 \pm 1{ }^{\circ} \mathrm{C} ; 70-85 \% \mathrm{RH}\right)$ during storage.

\subsubsection{Total Volatile Base Nitrogen (TVB-N) Analysis}

The determination of TVB-N content of shrimp flesh was carried out using the micro-diffusion Conway method [39]. The analysis consists of a trichloroacetic acid extraction followed by alkalinisation and incubation at $37^{\circ} \mathrm{C}$ for $60 \mathrm{~min}$. Finally, the total volatile bases in a boric acid solution were titrated with hydrochloric acid and their concentration expressed as $\mathrm{N} \mathrm{mg/100} \mathrm{g} \mathrm{sample.}$

\subsubsection{Microbiological Test}

Total plate count, yeast and mold counts and lactic acid bacteria (LAB) count of the samples (durian and shrimp) was performed according to the ICMSF methods for microbiological examination of foods [40]. A serial 10-fold dilution was prepared and $1 \mathrm{~mL}$ of appropriate decimal dilutions was poured on plate of total plate agar (PCA), potato dextrose agar (PDA) and Man Rogosa Sharpe (MRS) agar to determine total plate count, yeast and mold and lactic acid bacteria, respectively. The microbiological analysis was conducted in duplicates and the results were expressed as logarithm of colony forming units $(\log \mathrm{CFU} / \mathrm{g})$ of sample. 


\subsection{Statistical Analysis}

ANOVA was selected to compare the mean differences of the samples using statistical analysis system (SAS, Version 9.4) software. Meanwhile, Duncan's multiple range test was used to compare the differences for each change in $\mathrm{pH}$ solution [41]. The values were considered significantly different when $\mathrm{p}<0.05$.

\section{Results and Discussion}

\subsection{Determination of Anthocyanin Content in Samples of Clitoria sp and Brassica sp.}

In this study, the extract of Clitoria sp and Brassica sp were evaluated using Liquid chromatography-mass spectrometry (LCMS-QTOF-MS/MS). The results found that 12 different compounds of anthocyanin were successfully detected where ternatins were identified as the largest anthocyanin groups from Clitoria ternatea flowers comprising B1, B2, C1, D1 dan D2 types (Table 1). These results are consistent with the previous report showing that a variety of ternatin anthocyanin compounds were accumulated in Clitoria ternatea flowers [42]. Ternatins have become the largest monomeric anthocyanin which comprise delphinidin 3-O-(6"-O-malonyl)- $\beta$-glucoside derivatives substituted at both the $3^{\prime}-$ and $5^{\prime}-\mathrm{OH}$ groups with glucose or acylated glucose chains of various lengths [43].

Subsequently, the results of chromatographic analysis showed four different compounds of tentative anthocyanins were detected in extracted solution of Brassica sp, as shown in Table 1B. Contrary to the Clitoria sp, the most dominant anthocyanins detected in Brassica sp are cyanidin with four different moieties. The similar result have shown in previous studies where cyanidin is the most common in Brassica crops with quantitative differences among species and crops within the species $[44,45]$.

Table 1. Extract compound detected using LCMS-QTOF-MS/MS for (A) Clitoria sp; (B) Brassica sp.

\begin{tabular}{|c|c|c|c|c|}
\hline & Compound Detected & $\begin{array}{l}\text { Retention } \\
\text { Time (Min) }\end{array}$ & {$[\mathrm{M}]+(\mathrm{m} / \mathrm{z})$} & Formula \\
\hline (A) & Clitoria sp & & & \\
\hline 1 & Ternatin B1 & 29.45 & 1945.5063 & $\mathrm{C}_{90} \mathrm{H}_{97} \mathrm{O}_{48}$ \\
\hline 2 & Ternatin B2 & 29.37 & 1637.4229 & $\mathrm{C}_{75} \mathrm{H}_{81} \mathrm{O}_{41}$ \\
\hline 3 & Ternatin C1 & 19.43 & 1329.3364 & $\mathrm{C}_{60} \mathrm{H}_{65} \mathrm{O}_{34}$ \\
\hline 4 & Ternatin D1 & 35.67 & 1783.4616 & $\mathrm{C}_{84} \mathrm{H}_{87} \mathrm{O}_{43}$ \\
\hline 5 & Ternatin D2 & 32.41 & 1475.3745 & $\mathrm{C}_{69} \mathrm{H}_{71} \mathrm{O}_{36}$ \\
\hline 6 & Delphinidin-3-glucoside & 21.21 & 627.1696 & $\mathrm{C}_{27} \mathrm{H}_{31} \mathrm{O}_{17}$ \\
\hline 7 & Delfinidin & 26.08 & 303.0492 & $\mathrm{C}_{15} \mathrm{H}_{11} \mathrm{O}_{7}$ \\
\hline 8 & Peonidin-3-O-glucoside & 31.01 & 625.1806 & $\mathrm{C}_{28} \mathrm{H}_{33} \mathrm{O}_{16}$ \\
\hline 9 & Peonidin 3-sambubioside & 20.19 & 595.1663 & $\mathrm{C}_{27} \mathrm{H}_{31} \mathrm{O}_{15}$ \\
\hline 10 & 3-O-beta-D-glucoside 5-O-(6-coumaroyl-beta-D-glucoside & 34.92 & 757.1982 & $\mathrm{C}_{36} \mathrm{H}_{37} \mathrm{O}_{18}$ \\
\hline 11 & Cyanidin 3-(6"-caffeyl-2"' -sinapylsambubioside)-5-(6-malonylglucosid) & 24.23 & 1197.2949 & $\mathrm{C}_{55} \mathrm{H}_{57} \mathrm{O}_{30}$ \\
\hline 12 & $\begin{array}{c}\text { Cyanidin 3-O- [ 2-O- (6-O-E-coumaroyl-beta-D-glucopyanosyl) ] -\{6-O- [ 4-O- } \\
\text { (6-O-E-coumaroyl-beta-D-glucopyranosyl) -E-caffeoyl ] } \\
\text {-beta-D-glucopyranosyl\}-5-O-beta-D-glucopyranoside }\end{array}$ & 32.04 & 1197.2949 & $\mathrm{C}_{66} \mathrm{H}_{69} \mathrm{O}_{33}$ \\
\hline (B) & Brassica sp & & & \\
\hline 1 & Cyanidin 3,3',5-tri-O-glucoside & 13.88 & 773.2151 & $\mathrm{C}_{33} \mathrm{H}_{41} \mathrm{O}_{21}$ \\
\hline 2 & Cyanidin 3-(6" $6^{\prime \prime}$-sinapylsophoroside)-5-glucoside & 21.13 & 979.2714 & $\mathrm{C}_{44} \mathrm{H}_{51} \mathrm{O}_{25}$ \\
\hline 3 & Cyanidin 3-(diferuloylsophoroside) 5-glucoside & 34.39 & 1125.3103 & $\mathrm{C}_{53} \mathrm{H}_{57} \mathrm{O}_{27}$ \\
\hline 4 & $\begin{array}{c}\text { Cyanidin } \\
\text { 3-O-[beta-D-glucopyranoside]-7,3'-di-O-[6-O-(sinapyl)-beta-D-glucopyranoside }\end{array}$ & 34.82 & 1185.3305 & $\mathrm{C}_{55} \mathrm{H}_{61} \mathrm{O}_{29}$ \\
\hline
\end{tabular}

\subsection{Colour of Mixed and Single Natural Dyes Containing Anthocyanin in Buffer Solution ( $p H$ 1-13)}

Figure 1 shows the color changes in different sample consists of mixed natural dye solution (Brassica sp + Clitoria sp); (b) Brassica sp; (c) Clitoria sp; and (d) the developed colorimetric $\mathrm{pH}$ sensor film in different $\mathrm{pH}$ buffers ( $\mathrm{pH} 1-13)$. Clearly, the mixed natural dye (Figure 1A) was capable of producing 
distinct color changes over a wide range of $\mathrm{pH}$ values compared to single extract (Figure $1 \mathrm{~B}, \mathrm{C}$ ). As it can be seen, the mix solution presented a red color for the $\mathrm{pH}$ solution below $\mathrm{pH} 4.0$ and changed to purple around $\mathrm{pH}$ 5.0. Then, it turned from blue to green in the $\mathrm{pH}$ range from 6.0 to 11.0. Finally, yellow at $\mathrm{pH}$ solution was above 12.0. Similarly, the developed colorimetric $\mathrm{pH}$ sensor film showed that the color variation is dependent on $\mathrm{pH}$ changes and the its color changes were easily distinguishable one from another at different $\mathrm{pH}$ (Figure 1D).

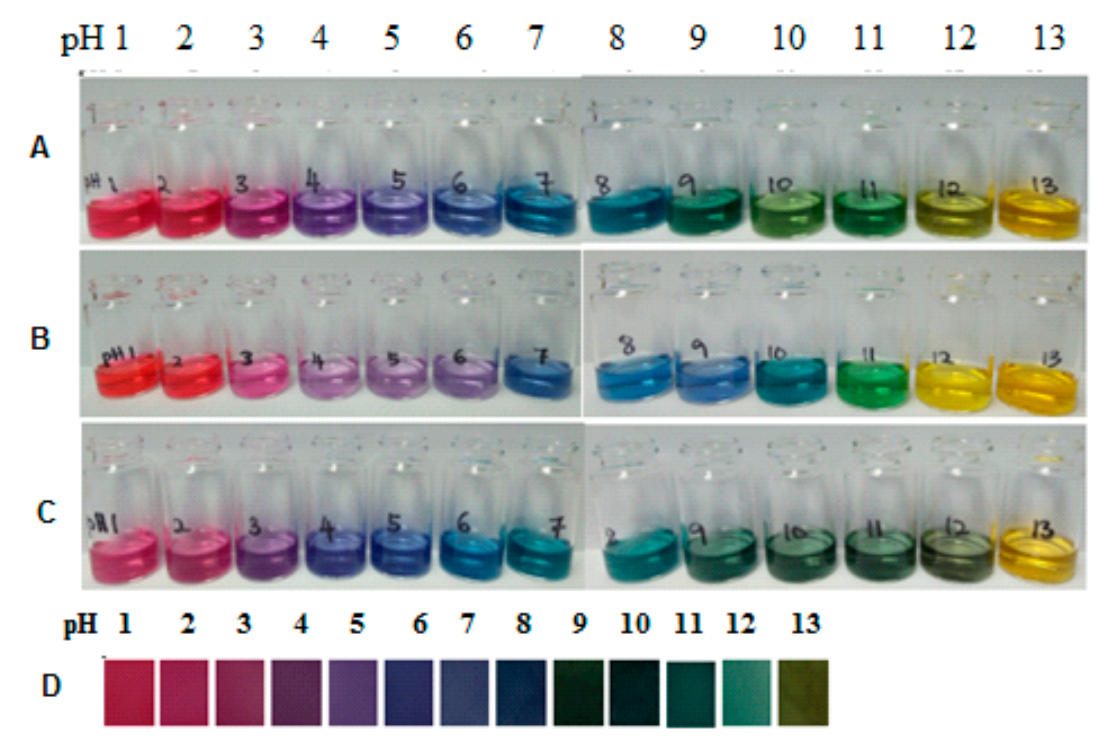

Figure 1. The color of solutions of (A) mixed natural dye (Brassica sp + Clitoria sp); (B) Brassica sp; (C) Clitoria sp extract) and (D) Colorimetric $\mathrm{pH}$ sensor film in different $\mathrm{pH}$ buffers solution ( $\mathrm{pH}$ 1-13).

\subsection{UV-vis Spectra of the Mixture and Single Extracts of Natural Dye in Various $p H$ Ranges}

Corresponding to color changes in Figure 1, UV-vis measurement was employed to investigate absorption spectra for each mixture solution in the region from $380 \mathrm{~nm}$ to $800 \mathrm{~nm}$. It is pertinent to point out that the observed spectra produced in this study relied on the anthocyanin contents whether the flavylium cation or quinonoidal base form of which is a major component in this system [46]. The UV-vis results indicates that the absorption spectra of mixture $\mathrm{pH}$ (Figure 2A) are able to produce maximum absorbance peak at different wavelengths compared a single extract (Figure 2B,C. As can be seen, UV absorption was measured at $527 \mathrm{~nm}$ and $530 \mathrm{~nm}$, respectively for $\mathrm{pH} 1$ and 2. Moreover, two maximum absorption peaks and a small shoulder peak were observed at a wavelength of $571 \mathrm{~nm}$ and $619 \mathrm{~nm}(\mathrm{pH}$ 4), $574 \mathrm{~nm}$ and $615 \mathrm{~nm}(\mathrm{pH}$ ) ) and $577 \mathrm{~nm}$ and $618 \mathrm{~nm}$ (pH 6), respectively. These two maximum peaks are representing the quinonoidal base and anionic quinonoidal base. While small shoulder peak could be attributed to the flavylium cation species. This characteristic is commonly exhibited by acylated B-ring substituted anthocyanin as can be seen in a previous study [47]. Furthermore, as the $\mathrm{pH}$ increased above 7.0, the maximum absorption of the peak shifted to a value more than $600 \mathrm{~nm}$. This shift also known as bathochromic shift commonly found in anthocyanins [48].

Furthermore, the resulting absorption spectra for the colorimetric $\mathrm{pH}$ sensor film in different $\mathrm{pH}$ buffers solution ( $\mathrm{pH} 1-13)$ demonstrated the maximum absorption display wavelength $\left(\lambda_{\max }\right)$ at $530 \mathrm{~nm}$ for $\mathrm{pH}$ lower than 4.0 (Figure 2D). These can be concluded that when the absorbance value decreases, $\mathrm{pH}$ also tends to increases and resulting in the color of the film changing from red to purple. Moreover, a new peak at $570 \mathrm{~nm}$ appeared when the $\mathrm{pH}$ of the sensing film increased to 5, 6 and 7 . The absorption peak at $620 \mathrm{~nm}$ was found at $\mathrm{pH} 8.0$ and above. Meanwhile, the absorption intensity of $620 \mathrm{~nm}$ increased when the solution $\mathrm{pH}$ increased from $\mathrm{pH} 8.0$ to 10.0 and the color of sensing film changed from blue to green as shown in Figure 1B. However, no absorption peak wavelength is found in the wavelength range of $450-800 \mathrm{~nm}$ at $\mathrm{pH} 13.0$. It may be caused by the degradation of anthocyanin compound at extreme pH values. According to Giusti \& Wrolstad [25], the isolated anthocyanins are 
highly unstable and very susceptible to degradation where their stability is very much dependent on pH value.
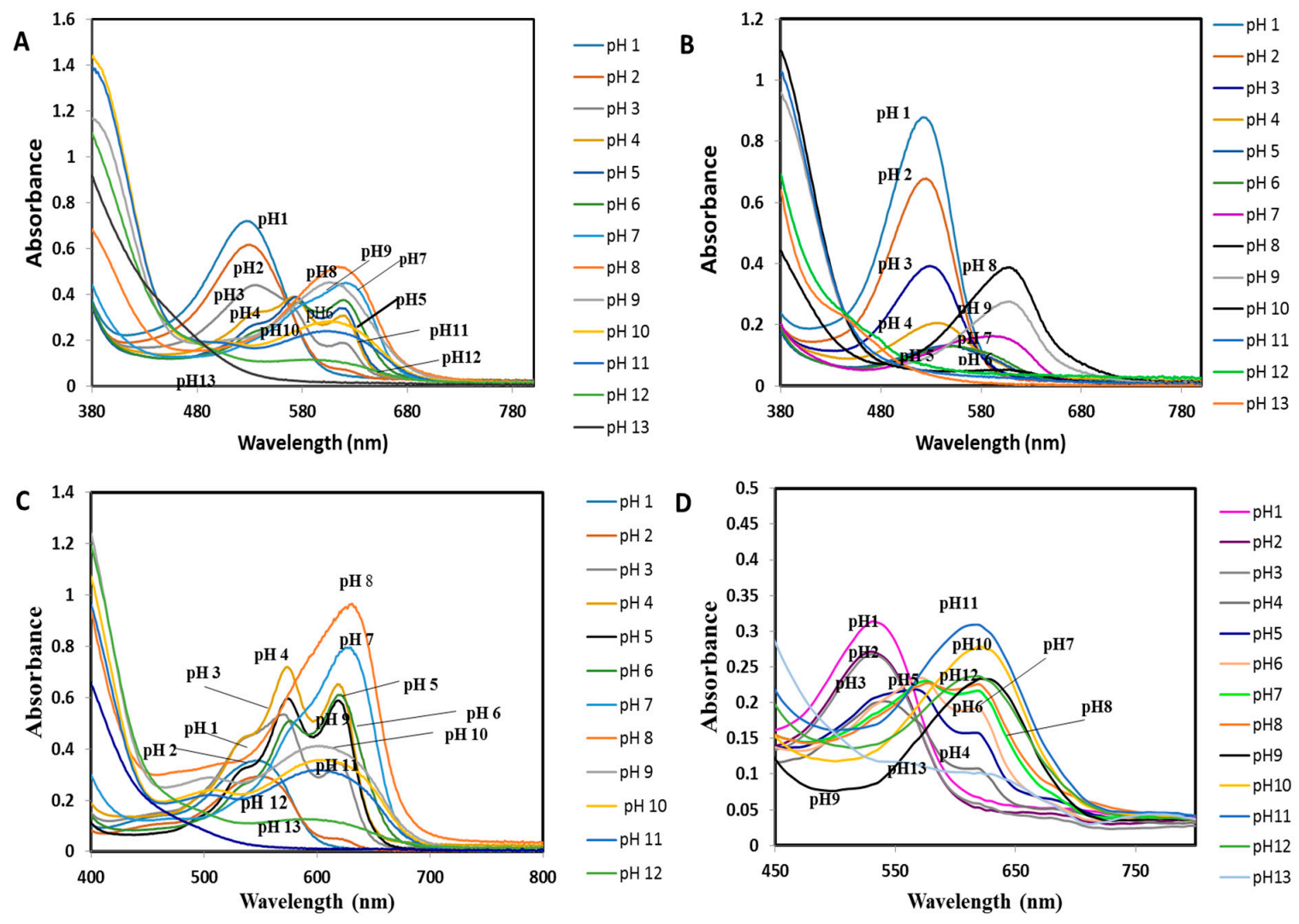

Figure 2. UV-vis spectra of the non-immobilized dye extracts of (A) mixed natural dyes (Brassica sp + Clitoria sp); (B) Brassica sp; (C) Clitoria sp; and (D) Colorimetric $\mathrm{pH}$ sensor film in different buffers ( $\mathrm{pH} 1-13)$.

\subsection{Chroma Colour Parameter Values}

The chromametry value $\left(\mathrm{L}^{*}, \mathrm{a}^{*}, \mathrm{~b}^{*}, \mathrm{C}^{*}\right.$ and $\left.\Delta \mathrm{E}^{*}\right)$ obtained in this study was further analyzed to see the variation in their mean at different $\mathrm{pH}$ buffer (significant level $\mathrm{p}<0.05$ ). As can be seen in Table 2 , the lightness $\left(\mathrm{L}^{*}\right)$ of the film was found decreased significantly $(\mathrm{p}<0.05)$ as decreased the $\mathrm{pH}$ value. The degradation of color lightness can be attributed to the degradation of antrocyinin at higher $\mathrm{pH}$ as suggested in previous studies [49].

Subsequently, $\mathrm{a}^{*}$ value exhibited significant difference at different range $\mathrm{pH}$ buffer, suggesting that the colorimetric $\mathrm{pH}$ sensor film was graded towards red within the buffer range of $\mathrm{pH} 1$ to $\mathrm{pH} 3$. While the red color could be assigned to the flavylium cation form of the anthocyanin structures that appears when anthocyanin in strongly acidic medium [50]. However, the colorimetric $\mathrm{pH}$ sensor film showed a negative values for the parameter $\mathrm{a}^{*}$ starting at $\mathrm{pH} 9.0(-9.41 \pm 0.02)$ and being more distinct at $\mathrm{pH} 11.0(-14.72 \pm 0.27)$ where color changes can be seen on the colorimetric $\mathrm{pH}$ sensor film from red to bright green color.

Furthermore, the highest negative values for parameter $b^{*}$ obtained indicates the presence of blue color visually displayed at pH 6.0, followed by pH 7.0 and $\mathrm{pH} 8.0$ with values of $-20.01 \pm 0.02$, $-18.36 \pm 0.29$ and $-18.25 \pm 0.01$, respectively. Meanwhile, the chroma $\left(C^{*}\right)$ of the film shows decrease with increasing in $\mathrm{pH}$ value $(\mathrm{p}<0.05)$ where the sensing film gave the brighter color in acidic $\mathrm{pH}$ buffer solution ( $\mathrm{pH} 1-2)$. However, color intensity gradually fade away whereas the chromatic $\left(\mathrm{C}^{*}\right)$ value of film are decreases in the alkaline $\mathrm{pH}$ range and being more evident at $\mathrm{pH} 9.0$ (11.06 \pm 0.01$)$. These phenomena can be related to the deprotonated of cynadin molecules occurring at high $\mathrm{pH}$ to form an anion which contributed to the cynadin degradation in the film [50]. The results from 
the data obtained conclude that $83.08 \%$ of the data show significant differences $(\mathrm{p}<0.05)$ for color parameters $\left(\mathrm{L}^{*}, \mathrm{a}^{*}, \mathrm{~b}^{*}, \mathrm{C}^{*}\right.$ and $\left.\Delta \mathrm{E}^{*}\right)$ in different buffers. This result demonstrated that the developed film owing a significant color variation enabling color variability to the human eye. Particularly, the color parameters $\mathrm{a}^{*}$ and $\mathrm{C}^{*}$ showed the highest number of significant difference between their values and $\mathrm{pH}$. Thus, both of these color parameters could be used as a primary assessment of the color change of the sensor in response to the $\mathrm{pH}$ changes.

Table 2. Color parameters changes $\left(\mathrm{L}^{*}, \mathrm{a}^{*}, \mathrm{~b}^{*}, \mathrm{C}^{*}\right.$ and $\left.\Delta \mathrm{E}^{*}\right)$ of colorimetric $\mathrm{pH}$ sensor film at different buffers.

\begin{tabular}{cccccc}
\hline $\mathbf{p H}$ & $\mathbf{L}^{*}$ & $\mathbf{a}^{*}$ & $\mathbf{b}^{*}$ & $\mathbf{C}^{*}$ & $\Delta \mathbf{E}^{*}$ \\
\hline 1.0 & $62.23 \pm 0.03^{\mathrm{B}}$ & $47.23 \pm 0.06^{\mathrm{A}}$ & $5.24 \pm 0.04^{\mathrm{B}}$ & $47.51 \pm 0.06^{\mathrm{A}}$ & $57.74 \pm 0.06^{\mathrm{A}}$ \\
2.0 & $64.30 \pm 0.04^{\mathrm{A}}$ & $43.79 \pm 0.04^{\mathrm{B}}$ & $0.50 \pm 0.04^{\mathrm{C}}$ & $43.79 \pm 0.04^{\mathrm{B}}$ & $53.78 \pm 0.05^{\mathrm{C}}$ \\
3.0 & $61.89 \pm 0.01^{\mathrm{C}}$ & $35.87 \pm 0.04^{\mathrm{C}}$ & $-4.41 \pm 0.03^{\mathrm{E}}$ & $36.14 \pm 0.04^{\mathrm{C}}$ & $49.60 \pm 0.04^{\mathrm{E}}$ \\
4.0 & $60.75 \pm 0.05^{\mathrm{D}}$ & $24.74 \pm 0.05^{\mathrm{D}}$ & $-12.32 \pm 0.02^{\mathrm{I}}$ & $27.64 \pm 0.05^{\mathrm{D}}$ & $45.16 \pm 0.02^{\mathrm{G}}$ \\
5.0 & $59.24 \pm 0.20^{\mathrm{E}}$ & $19.09 \pm 0.14^{\mathrm{E}}$ & $-17.12 \pm 0.17^{\mathrm{J}}$ & $25.64 \pm 0.21^{\mathrm{E}}$ & $45.47 \pm 0.23^{\mathrm{G}}$ \\
6.0 & $57.91 \pm 0.24^{\mathrm{G}}$ & $11.02 \pm 0.05^{\mathrm{F}}$ & $-20.01 \pm 0.02^{\mathrm{L}}$ & $22.84 \pm 0.04^{\mathrm{F}}$ & $45.18 \pm 0.22^{\mathrm{G}}$ \\
7.0 & $59.44 \pm 0.48^{\mathrm{E}}$ & $7.49 \pm 0.26^{\mathrm{G}}$ & $-18.36 \pm 0.29^{\mathrm{K}}$ & $19.83 \pm 0.37^{\mathrm{G}}$ & $42.28 \pm 0.67^{\mathrm{I}}$ \\
8.0 & $54.08 \pm 0.03^{\mathrm{I}}$ & $6.92 \pm 0.02^{\mathrm{H}}$ & $-18.25 \pm 0.01^{\mathrm{K}}$ & $19.52 \pm 0.02^{\mathrm{H}}$ & $46.71 \pm 0.04^{\mathrm{F}}$ \\
9.0 & $43.20 \pm 0.03^{\mathrm{J}}$ & $-9.41 \pm 0.02^{\mathrm{K}}$ & $-5.82 \pm 0.01^{\mathrm{F}}$ & $11.06 \pm 0.01^{\mathrm{M}}$ & $53.18 \pm 0.03^{\mathrm{D}}$ \\
10.0 & $40.86 \pm 0.03^{\mathrm{K}}$ & $-8.66 \pm 0.02^{\mathrm{J}}$ & $-9.85 \pm 0.02^{\mathrm{H}}$ & $13.12 \pm 0.01^{\mathrm{L}}$ & $56.15 \pm 0.03^{\mathrm{B}}$ \\
11.0 & $56.07 \pm 0.56^{\mathrm{H}}$ & $-14.72 \pm 0.27^{\mathrm{M}}$ & $-7.98 \pm 0.18^{\mathrm{G}}$ & $16.75 \pm 0.31^{\mathrm{I}}$ & $42.83 \pm 0.71^{\mathrm{H}}$ \\
\hline
\end{tabular}

Average values $(n=5)$ with the same superscript within a column are not significantly different at $5 \%$ level $(\mathrm{p}>0.05)$. Number of data demonstrated Significant difference: $L^{*}=9 ; a^{*}=13 ; b^{*}=11 ; C^{*}=13 ; \Delta E^{*}=8$. Total significant $=54$. Significant data percentage $=83.08 \%$.

In addition, correlation studies have been carried out between each chromametric parameter and different $\mathrm{pH}$ range to find out the most significant parameter correlated in the particular $\mathrm{pH}$ range. In this studies, the highest correlation coefficients $\left(\mathrm{R}^{2}\right)$ value was obtained in selected $\mathrm{pH}$ ranged as shown in Table 3 indicates that colorimetric $\mathrm{pH}$ sensor film would have better color distinction in those $\mathrm{pH}$. In general, the results showed that all of the chromametrics parameters $\left(\mathrm{L}^{*}, \mathrm{a}^{*}, \mathrm{~b}^{*}, \mathrm{C}^{*}, \Delta \mathrm{E}^{*}\right)$ of the colorimetric $\mathrm{pH}$ sensor film are well correlated with the $\mathrm{pH}$ values (Table 3). Among these, the $\mathrm{a}^{*}$ value had displayed a strong correlation with widest $\mathrm{pH}$ range $\left(\mathrm{R}^{2}=0.97391\right)$, followed by $\mathrm{C}^{*}\left(\mathrm{R}^{2}=0.94694\right), \Delta \mathrm{E}^{*}\left(\mathrm{R}^{2}=0.93431\right.$ at $\left.\mathrm{pH} 1-5\right), \mathrm{b}^{*}\left(\mathrm{R}^{2}=0.86177\right), \Delta \mathrm{E}^{*}\left(\mathrm{R}^{2}=0.93431\right.$ at $\mathrm{pH}$ 6-10) and $\mathrm{L}^{*}$ value $\left(R^{2}=0.76366\right)$ respectively. Therefore, it can be concluded that $a^{*}$ parameter implies the best color parameter can be used as food spoilage assessment. However, since all the color parameters $\left(L^{*}, a^{*}, b^{*}\right.$, $\mathrm{C}^{*}$ and $\Delta \mathrm{E}^{*}$ ) are quantitatively measured and display a good correlation with $\mathrm{pH}$, others parameter is also possible to be use as food monitoring along with suggested parameter.

Table 3. Quantitative data on the linear relationship between color parameters $\left(\mathrm{L}^{*}, \mathrm{a}^{*}, \mathrm{~b}^{*}, \mathrm{C}^{*}\right.$ and $\left.\Delta \mathrm{E}^{*}\right)$ and $\mathrm{pH}$.

\begin{tabular}{cccc}
\hline Correlation Parameter (y) & $\mathbf{p H}$ Range (x) & $\begin{array}{c}\text { Linear Correlation Relationship } \\
(\mathbf{n}=\mathbf{5} \text { Data Points) }\end{array}$ & $\mathbf{R}^{\mathbf{2}}$ \\
\hline $\mathrm{L}^{*}$ & $1-10$ & $\mathrm{y}=-2.3293 x+69.201$ & 0.76366 \\
$\mathrm{a}^{*}$ & $1-10$ & $\mathrm{y}=-6.5453 \mathrm{x}+53.807$ & 0.97391 \\
$\mathrm{~b}^{*}$ & $1-8$ & $\mathrm{y}=-3.6944 \mathrm{x}+6.0336$ & 0.86177 \\
$\mathrm{C}^{*}$ & $1-9$ & $\mathrm{y}=-4.2672 \mathrm{x}+49.555$ & 0.94694 \\
$\Delta \mathrm{E}^{*}$ & $1-5$ & $\mathrm{y}=-3.316 \mathrm{x}+60.298$ & 0.93431 \\
$\Delta \mathrm{E}^{*}$ & $6-10$ & $\mathrm{y}=3.284 \mathrm{x}+22.428$ & 0.81002 \\
\hline
\end{tabular}

\subsection{Repeatability and Reproducibility Studies}

The repeatability of colorimetric $\mathrm{pH}$ sensor film was studied using three different buffers consists of $\mathrm{pH} 4$, pH 7 and pH 12 and measured using UV-vis spectroscopy by referring at UV adsorption 
values. The results obtained are shown in Figure 3A for both wavelengths $530 \mathrm{~nm}$ and $620 \mathrm{~nm}$. As a result, the relative standard deviation (RSD) values were obtained at $\mathrm{pH} 4, \mathrm{pH} 7$ and $\mathrm{pH} 12$ was $2.26 \%$, $1.64 \%$ and $2.85 \%$ (absorption at $530 \mathrm{~nm}$ wavelength), respectively. While RSD values obtained at the same $\mathrm{pH}$ was $1.40 \%, 1.55 \%$ and $2.06 \%$ for the $620 \mathrm{~nm}$ wavelengths, respectively. All of these RSD values can be described as a low and acceptable which indicates homogeneously dispersed between a mixture of natural dye and thickness of the colorimetric $\mathrm{pH}$ sensor film.

Furthermore, Figure 3B shows the results of reproducibility studies of colorimetric $\mathrm{pH}$ sensor film were carried out on the same condition as repeatability studies. As a result, the RSD values for $\mathrm{pH} 4$, pH 7 and pH 12 was determined to be $2.47 \%, 1.25 \%$ and 3.28\%, respectively for the absorption at $530 \mathrm{~nm}$ wavelengths, while values of $4.62 \%, 1.08 \%$ and $4.05 \%$ for the absorption wavelength at $620 \mathrm{~nm}$. This result shows that the resulting RSD value is higher than the repeatability and indirectly indicates that the colorimetric $\mathrm{pH}$ sensor film has better repeatability than its reproducibility.

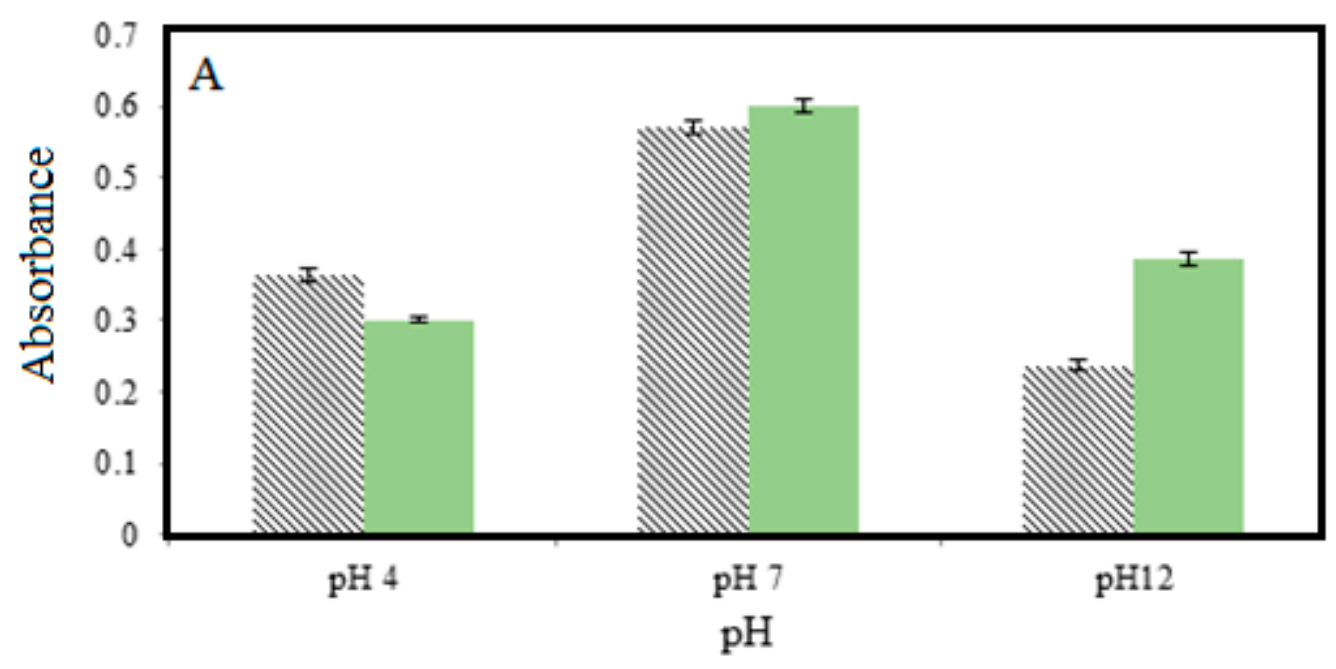

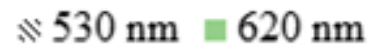

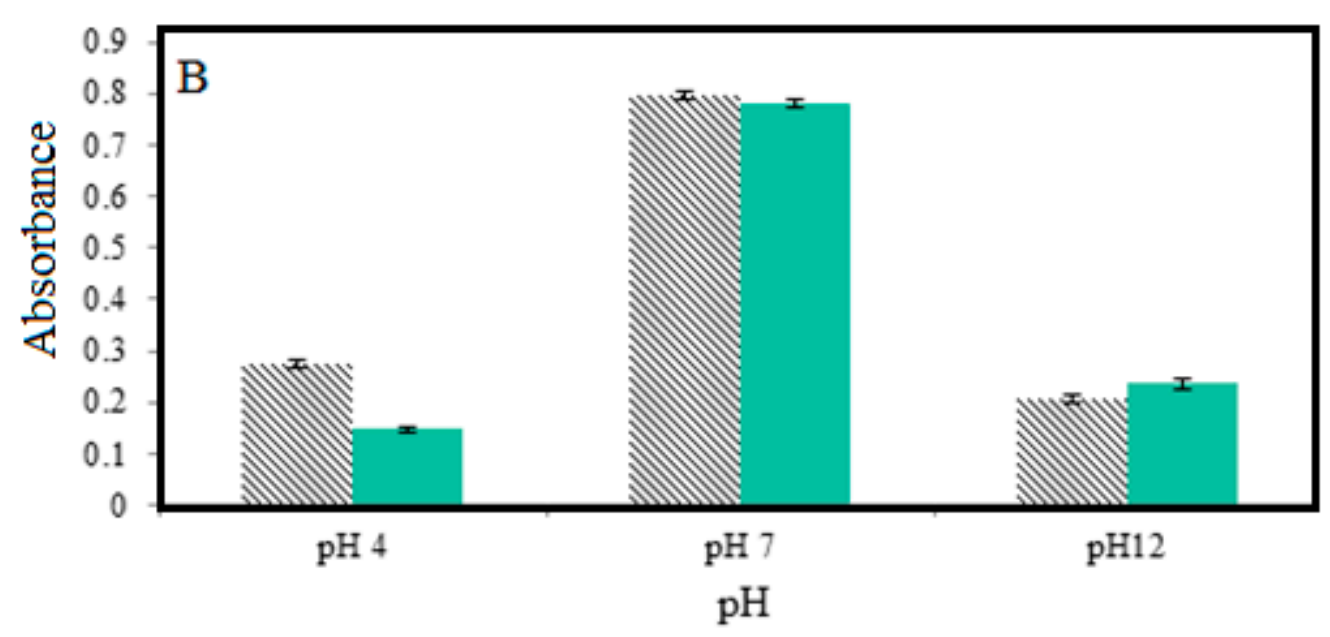

Figure 3. (A) Graph of repeatability and (B) reproducibility of colorimetric $\mathrm{pH}$ sensor film in different buffer solutions. 


\subsection{Sensor Response of Food Samples}

\subsubsection{Sensor Response of Food Samples during Storage}

Two types of food sample were use as real samples to demonstrated the effectiveness colorimetric $\mathrm{pH}$ sensor film. In this study, fresh shrimp and durian samples were tested using the colorimetric $\mathrm{pH}$ sensor film in food spoilage evaluation stored at ambient temperature $\left(28 \pm 1{ }^{\circ} \mathrm{C} ; 70-85 \% \mathrm{RH}\right)$.

Table 4 shows the changes in color parameters $\left(\mathrm{L}^{*}, \mathrm{a}^{*}, \mathrm{~b}^{*}, \mathrm{C}^{*}\right.$ and $\left.\Delta \mathrm{E}^{*}\right)$ of the colorimetric $\mathrm{pH}$ sensor film throughout storage at ambient temperature for shrimp and durian samples, respectively. For shrimp samples, the $L^{*}$ value is found decreased with the increasing storage time, resulting the film became darker. Subsequently, the negative $a^{*}$ value is detected on the colorimetric $\mathrm{pH}$ sensor film in the $\mathrm{pH} 9$ buffer. These results demonstrated the ability of colorimetric $\mathrm{pH}$ sensor film to change its color that occurred at this $\mathrm{pH}$ value ascribed the result to the the chemical reaction between anthocyanin compounds in the form of anhydro bases and the spoilage metabolites [51]. While, the value of $\mathrm{b}^{*}$ showed decreased throughout storage periods exhibited diminishing of the blue color on the colorimetric $\mathrm{pH}$ sensor film (Figure $4 \mathrm{~A}, \mathrm{~B}$ ).

On the other hand, the results on the durian sample also displayed decreases in $L^{*}$ value pattern throughout 6 days of the storage and the film became darker until the end of the storage time. Subsequently, the same pattern was observed at $a^{*}$ value in a first two days where the color colorimetric $\mathrm{pH}$ sensor film turned to distinct red after 6 days of durian storage. However, the pattern changes to increase at day 4 of the storage time. The results of this outcome is difficult to be explain however it could be due to anthocyanins nature properties where in nature they are highly unstable and are susceptible to degradation according to the material of food used. Moreover, negative values of $b^{*}$ (blue) decreased to $-2.93 \pm 0.04$ at day 4 of the storage time where the appearance of dark purple are visible on the colorimetric $\mathrm{pH}$ sensor film (Figure 4C,D). This change may be due to the degradation of food metabolites leading to a $\mathrm{pH}$ decrease in headspace. Similar results are shown on the color intensity value $\left(C^{*}\right)$ showed decreases in pattern with increases the storage time for both samples. This pattern could be due to the change of $a^{*}$ and $b^{*}$ values since both parameters have a great influence on the changes of color intensity $\left(C^{*}\right)$. While, total color difference $\left(\Delta \mathrm{E}^{*}\right)$ also increased as increases the storage time with the value obtained was $56.27 \pm 0.84$ on the first day and keep increasing until $70.67 \pm 0.27$ on day 4 .

Table 4. Parameters changes $\left(\mathrm{L}^{*}, \mathrm{a}^{*}, \mathrm{~b}^{*}, \mathrm{C}^{*}\right.$ and $\left.\Delta \mathrm{E}^{*}\right)$ of sensing film for packaged shrimp and durian stored at ambient temperature $\left(28 \pm 1^{\circ} \mathrm{C}\right)$.

\begin{tabular}{cccccc}
\hline Storage Time (h/day) & $\mathbf{L}^{*}$ & $\mathbf{a}^{*}$ & $\mathbf{b}^{*}$ & $\mathbf{C}^{*}$ & $\mathbf{E}^{*}$ \\
\hline Shrimp samples & & & & & \\
\hline $1.0 \mathrm{~h}$ & $36.81 \pm 0.62$ & $2.20 \pm 0.22$ & $-5.09 \pm 0.17$ & $5.55 \pm 0.20$ & $58.66 \pm 0.62$ \\
$2.0 \mathrm{~h}$ & $28.47 \pm 0.69$ & $0.04 \pm 0.08$ & $-5.13 \pm 0.26$ & $5.13 \pm 0.26$ & $66.87 \pm 0.76$ \\
$2.5 \mathrm{~h}$ & $26.91 \pm 0.65$ & $-0.09 \pm 0.22$ & $-4.72 \pm 0.38$ & $4.72 \pm 0.38$ & $68.37 \pm 0.63$ \\
$3.0 \mathrm{~h}$ & $26.31 \pm 0.73$ & $-0.64 \pm 0.10$ & $-4.44 \pm 0.41$ & $4.49 \pm 0.40$ & $68.93 \pm 0.70$ \\
$4.0 \mathrm{~h}$ & $25.73 \pm 0.20$ & $-1.18 \pm 0.10$ & $-3.57 \pm 0.79$ & $3.77 \pm 0.74$ & $69.43 \pm 0.25$ \\
\hline Durian samples & & & & & \\
\hline 0 day & $39.18 \pm 0.77$ & $3.62 \pm 0.22$ & $-4.13 \pm 0.31$ & $5.49 \pm 0.40$ & $56.27 \pm 0.84$ \\
2 day & $26.38 \pm 0.61$ & $-1.63 \pm 0.10$ & $-3.82 \pm 0.20$ & $4.15 \pm 0.23$ & $68.82 \pm 0.62$ \\
4 day & $24.50 \pm 0.28$ & $3.12 \pm 0.08$ & $-2.93 \pm 0.04$ & $4.28 \pm 0.08$ & $70.67 \pm 0.27$ \\
6 day & $25.58 \pm 0.11$ & $3.04 \pm 0.04$ & $-2.88 \pm 0.14$ & $4.19 \pm 0.13$ & $69.59 \pm 0.12$ \\
\hline
\end{tabular}



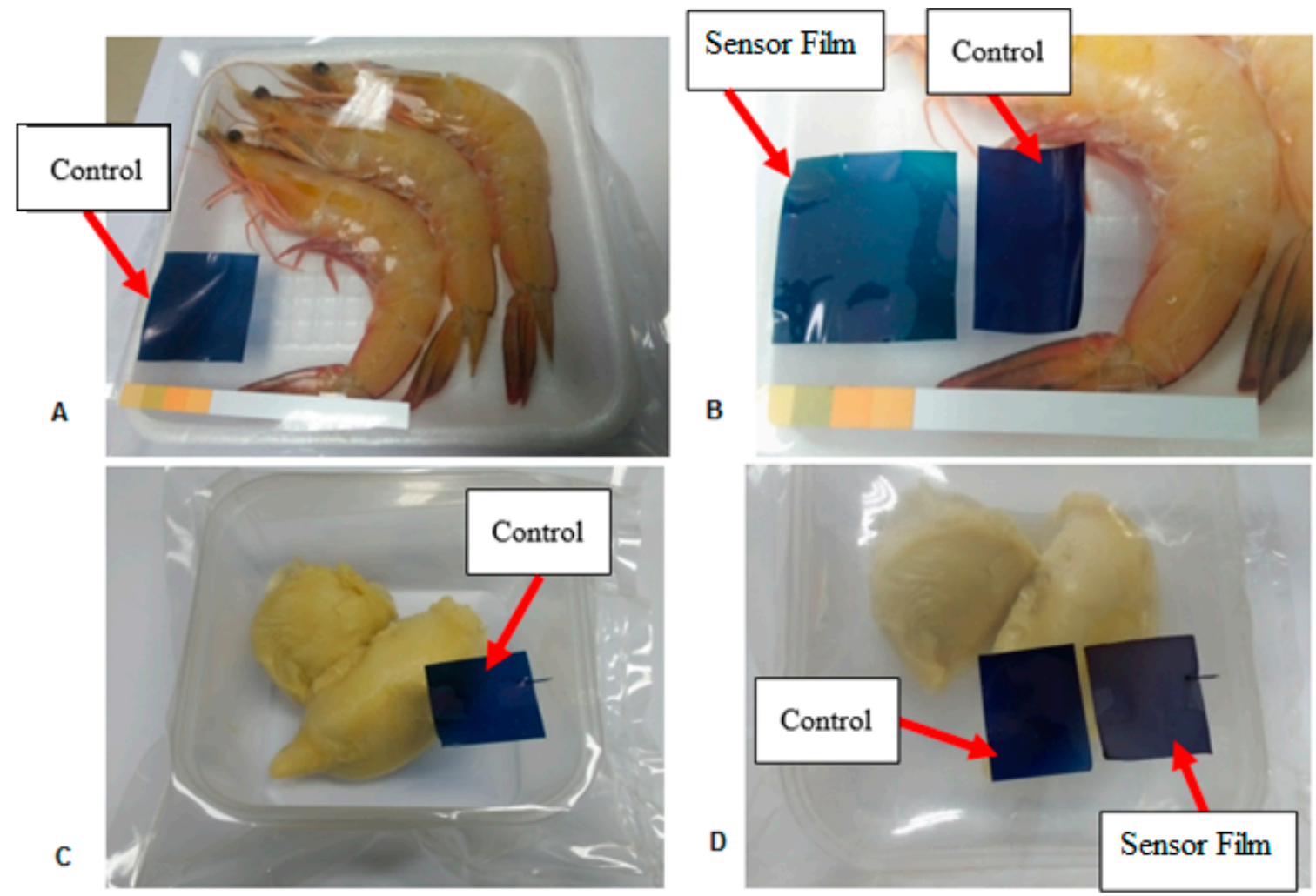

C

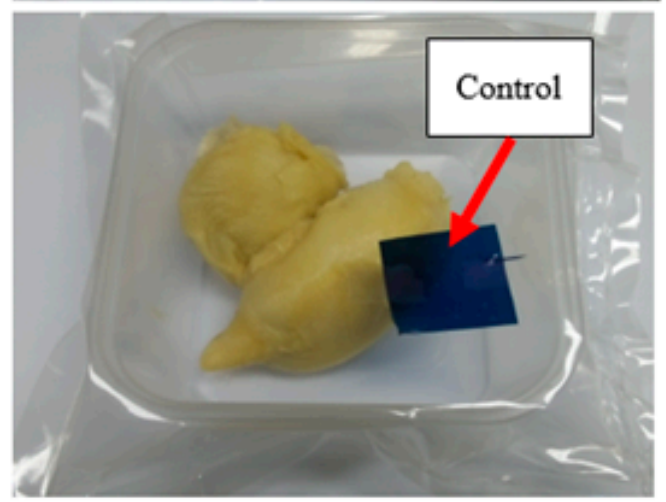

Figure 4. Application of sensing film for monitoring-(A) shrimp freshness at $0 \mathrm{~h}$ (i) and after $2.5 \mathrm{~h}$; (B) stored at ambient temperature; (C) durian freshness at: 0 days; (D) and after 4 days (ii) stored at ambient temperature.

\subsubsection{Correlation between $\mathrm{pH}$ Samples with Colorimetric Parameters for Shrimp and Durian Samples}

Figure 5A shows the correlation graph between color parameter of the developed colorimetric $\mathrm{pH}$ sensor film $\left(\mathrm{L}^{*}, \mathrm{a}^{*}, \mathrm{~b}^{*}, \mathrm{C}^{*}, \Delta \mathrm{E}^{*}\right)$ and $\mathrm{pH}$ value for fresh shrimp samples stored at $28.1 \pm 1{ }^{\circ} \mathrm{C}$ for $4 \mathrm{~h}$. In this study, the change of $\mathrm{a}^{*}$ value displays a strong relationship with the $\mathrm{pH}$ value compared to others color parameters (Figure $5 \mathrm{~B}$ ). These can be seen when the $\mathrm{pH}$ of the shrimp sample increased, negative value of $\mathrm{b} *$ also increase which also indicates the color of the film turned to greenish blue after $2.5 \mathrm{~h}$ of storage. Hence, it can be concluded that, the negative value for $\mathrm{a}$ * on the colorimetric $\mathrm{pH}$ sensor will increase as the freshness of the shrimp sample decrease.

While, Figure 5B represent correlation graph between color parameter $\left(\mathrm{L}^{*}, \mathrm{a}^{*}, \mathrm{~b}^{*}, \mathrm{C}^{*}, \Delta \mathrm{E}^{*}\right)$ and $\mathrm{pH}$ value for durian sample was stored at ambient temperature for 8 days. As a result, the value of $\mathrm{b}^{*}$ showed a highest correlation than other studied color parameters where the increases acidity of the durian sample (low $\mathrm{pH}$ value) exhibited the value of $b^{*}$ (referring to blue) decreased. Therefore, it can be concluded that the parameter color of $b^{*}$ value on the developed colorimetric $\mathrm{pH}$ sensor will decrease as there is decreases of quality durian sample freshness. The results also showed that the colorimetric $\mathrm{pH}$ sensor changed to purple dark on the 4th day of storage with a $\mathrm{pH}$ value detected was about $5.5 \pm 0.02$ which is considered not accepted as fresh edible durian [52]. 
A)
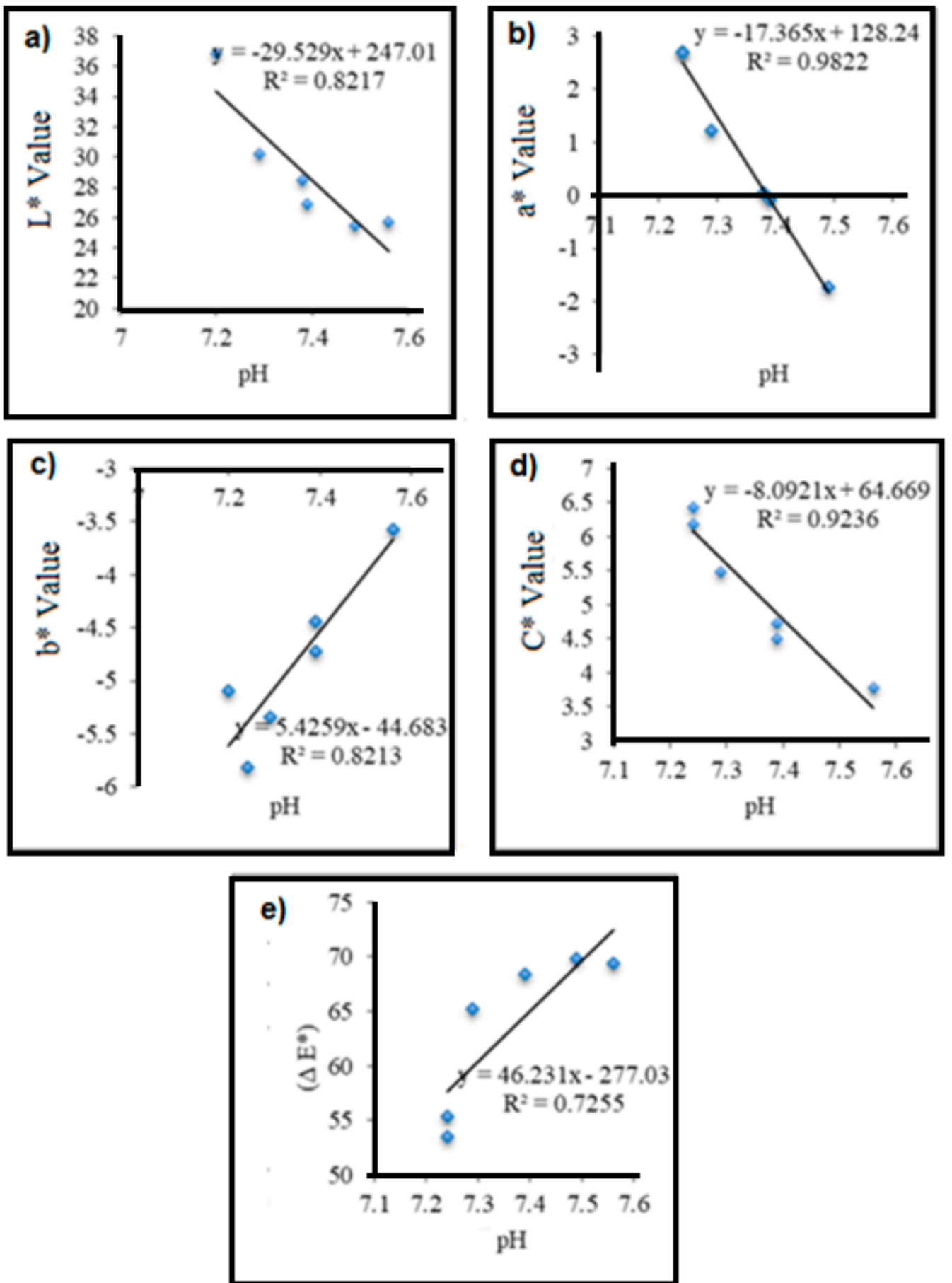

Figure 5. Cont. 

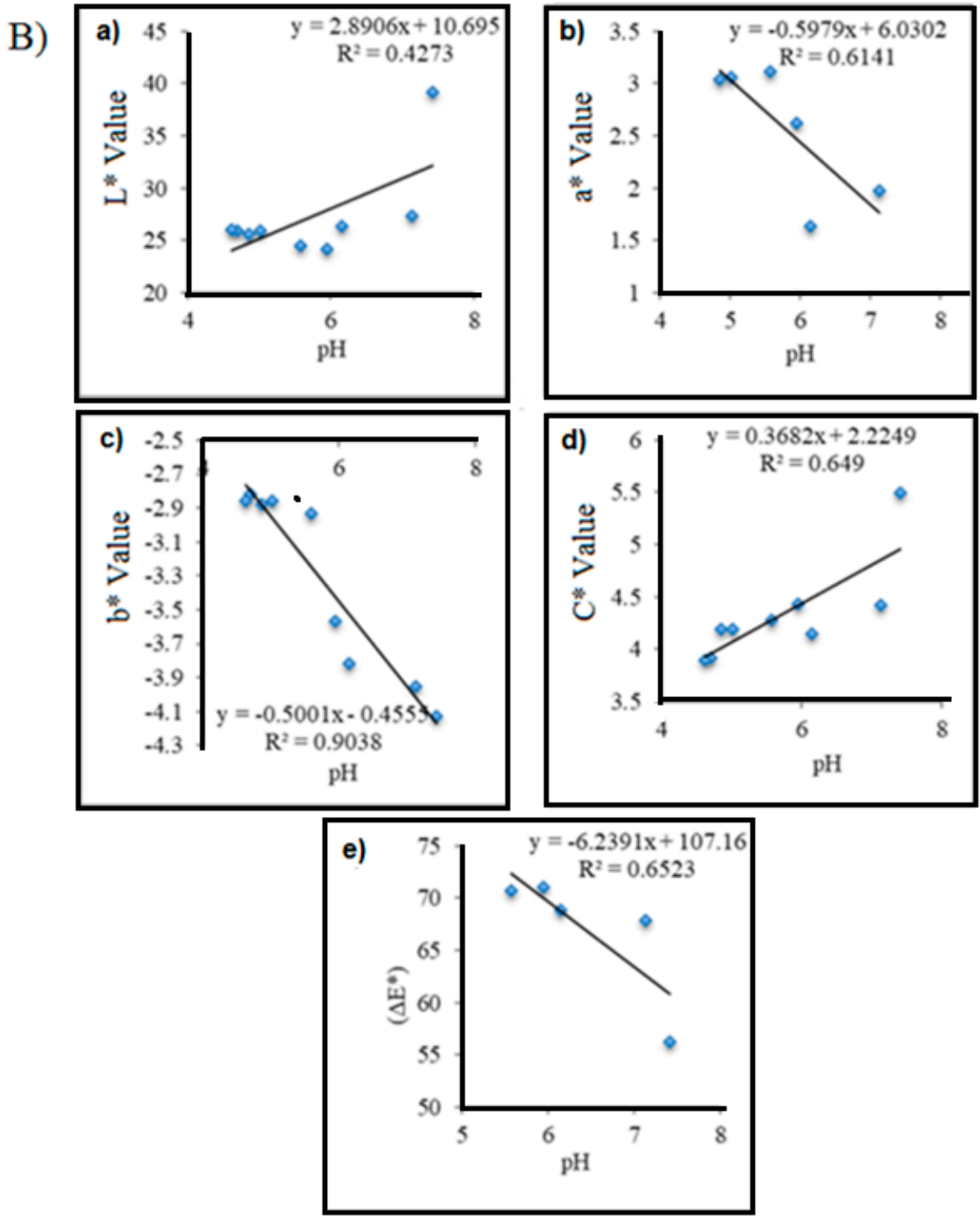

Figure 5. Sample of (A) shrimp samples (B) durian sample based on correlation studies between color parameter of colorimetric $\mathrm{pH}$ sensor film and $\mathrm{pH}$ values.

3.6.3. Correlation Study of the Colorimetric pH Sensor Film on the Freshness of Package Shrimps and Durians Stored at Ambient Temperature $\left(28 \pm 1^{\circ} \mathrm{C}\right)$

Correlation studies have been conducted between chromametrics parameter $\left(L^{*} a^{*} b^{*} c\right)$ and food spoilage parameter (TVB-N, pH, TPC, Yeast \& mold and LAB) to determine whether the correlation between these two variables is significant or not. In general, the value of chromametrics parameter $\left(L^{*} a^{*} b^{*} c\right)$ was found to have a good correlation with the food spoilage parameter (Table 5). Among these, $\mathrm{a}^{*}$ value showed correlate well to all food spoilage parameters involved compared 
to another chromametrics parameter throughout $4 \mathrm{~h}$ storage time for shrimp samples. Specifically, an increases pattern was observed for $-\mathrm{a}^{*}$ (negative value refers to green) as increased of TVB-N contents (Figure 6A), pH (Figure 6B), total plate counts (TPC) (Figure 6C) and yeast \& mold (Figure 6D), respectively, which represents the deterioration of food quality with the increasing storage time.

On the other hand, durian samples also showed fairly strong relationship between values of $L^{*}$, $a^{*}, b^{*}, C^{*}$ and food spoilage parameters (Table 5). Among these, $b^{*}$ value (refers to blue) significantly correlated with all the food spoilage parameter consists of $\mathrm{pH}$ (Figure 7A), total plate counts (TPC) (Figure 7B), Yeast and mold (Figure 7C) and lactic acid bacteria (LAB) (Figure 7D) by displaying strong correlation coefficients $\left(R^{2}>0.90\right)$ respectively. As it can be seen, the depreciation $-b^{*}$ value indicates less blue color was observed in colorimetric $\mathrm{pH}$ sensor film can be indicated the deterioration of the durian quality within 6 days of storage time.

Furthermore, the change in negative values of $a^{*}$ and $b^{*}$ explain the existence of correlation between the metabolites that caused food spoilage produced during storage time due to increase of TVB-N content, $\mathrm{pH}$ values and microbiology contents. Based on this result, two color parameters $\left(a^{*}\right.$ and $b^{*}$ ) have shown their suitability for quantitative measurement of packaged shrimp and durian samples quality using colorimetric $\mathrm{pH}$ sensor film developed by chromametry methods.
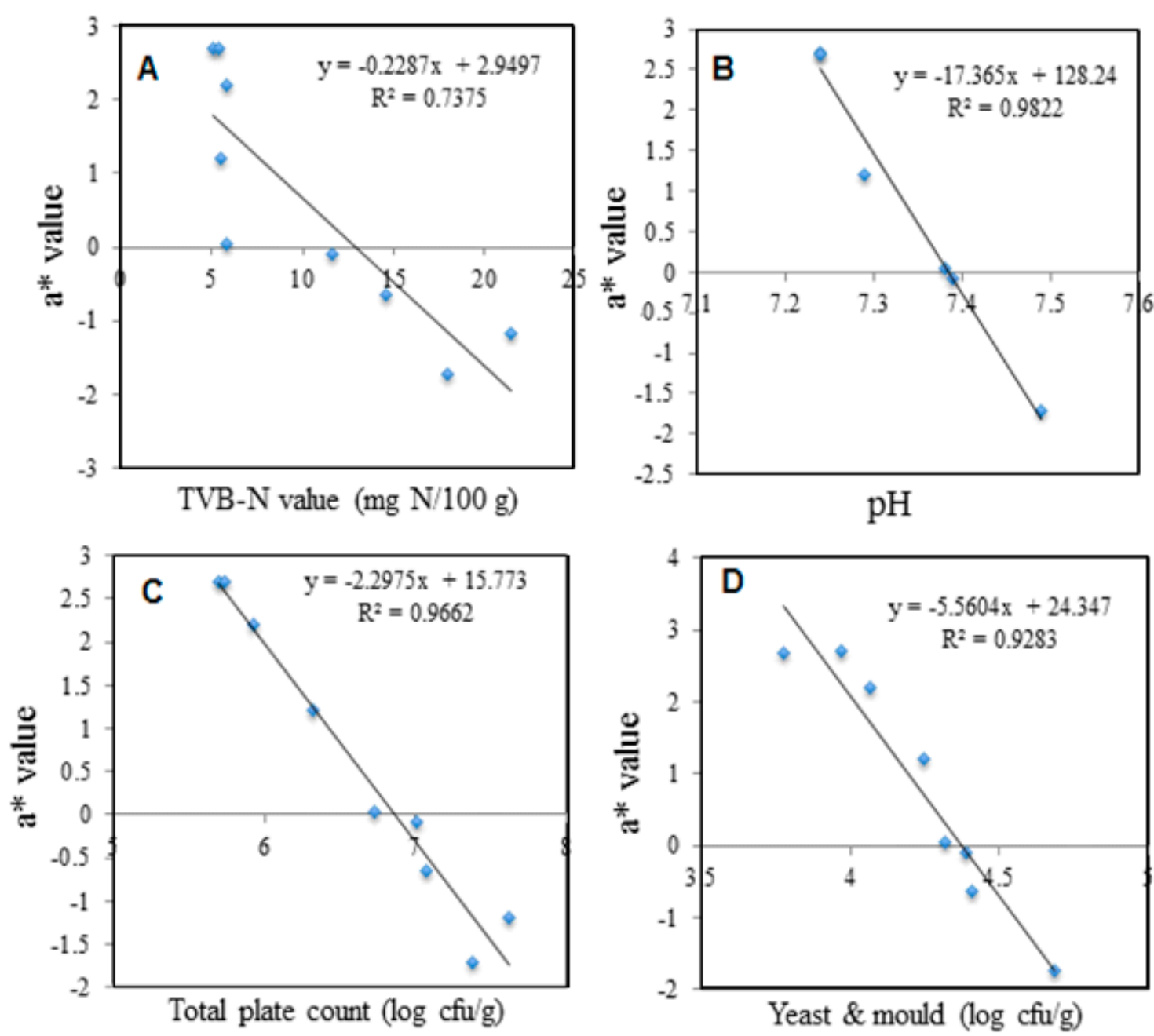

Figure 6. Correlation between $\mathrm{a}^{*}$ value of colorimetric $\mathrm{pH}$ sensor film with parameter analysis of shrimp samples-(A) TVB-N concentration; (B) pH value-(C) Total plate count (TPC); (D) Yeast and mold counts. 
Table 5. Correlation studies between color changes $\left(\mathrm{L}^{*}, \mathrm{a}^{*}, \mathrm{~b}^{*}, \mathrm{C}^{*}\right.$ and $\left.\Delta \mathrm{E}^{*}\right)$ of sensing film with spoilage parameters for shrimp and durian samples stored at ambient temperature $\left(28 \pm 1{ }^{\circ} \mathrm{C}\right)$.

\begin{tabular}{|c|c|c|c|c|c|}
\hline $\begin{array}{c}\text { Spoilage } \\
\text { Parameters }\end{array}$ & $\mathbf{L}^{*}$ & $a^{*}$ & $\mathbf{b}^{*}$ & $C^{*}$ & $\Delta \mathrm{E}^{*}$ \\
\hline \multicolumn{6}{|c|}{$\begin{array}{l}\text { Shrimp samples } \\
\text { Correlation }(n=5) \text { with }\end{array}$} \\
\hline TVBN & $\begin{array}{c}R 2=0.5300 \\
(y=-0.7604 x+39.259)\end{array}$ & $\begin{array}{c}R 2=0.7375 \\
(y=-0.2287 x+2.9497)\end{array}$ & $\begin{array}{c}R 2=0.7025 \\
(y=0.0887 x-5.886)\end{array}$ & $\begin{array}{c}R 2=0.6127 \\
(y=0.1025 x+6.2913)\end{array}$ & $\begin{array}{c}R 2=0.5271 \\
(y=0.7393 x+56.35)\end{array}$ \\
\hline $\mathrm{pH}$ & $\begin{array}{c}R 2=0.8217 \\
(y=-29.529 x+247.01)\end{array}$ & $\begin{array}{c}\mathrm{R} 2=0.9822 \\
(\mathrm{y}=-17.365 \mathrm{x}+128.24)\end{array}$ & $\begin{array}{c}R 2=0.8213 \\
(y=5.4259 x-44.683)\end{array}$ & $\begin{array}{c}\mathrm{R} 2=0.9236 \\
(\mathrm{y}=-8.0921 \mathrm{x}+64.669)\end{array}$ & $\begin{array}{c}R 2=0.7255 \\
(y=46.231 x-277.03)\end{array}$ \\
\hline ТPC & $\begin{array}{c}R 2=0.8872 \\
(y=-8.636 x+88.487)\end{array}$ & $\begin{array}{c}R 2=0.9662 \\
(y=-2.2975 x+15.773)\end{array}$ & $\begin{array}{c}\mathrm{R} 2=0.6887 \\
(\mathrm{y}=0.7707 x-10.063)\end{array}$ & $\begin{array}{c}R 2=0.7752 \\
(y=-1.0117 x+11.92)\end{array}$ & $\begin{array}{c}\mathrm{R} 2=0.8856 \\
(\mathrm{y}=8.4114 \mathrm{x}+8.3878)\end{array}$ \\
\hline Yeast \& mold & $\begin{array}{c}R 2=0.6648 \\
(y=-11.452 x+80.281)\end{array}$ & $\begin{array}{c}R 2=0.9283 \\
(y=-5.5604 x+24.347)\end{array}$ & $\begin{array}{c}\mathrm{R} 2=0.8842 \\
(\mathrm{y}=1.7352 \mathrm{x}-12.432)\end{array}$ & $\begin{array}{c}\mathrm{R} 2=0.8693 \\
(\mathrm{y}=-2.0813 \mathrm{x}+14.14)\end{array}$ & $\begin{array}{c}R 2=0.8544 \\
(y=21.044 x-25.782)\end{array}$ \\
\hline \multicolumn{6}{|c|}{$\begin{array}{l}\text { Durian samples } \\
\text { Correlation }(n=5) \text { with }\end{array}$} \\
\hline $\mathrm{pH}$ & $\begin{array}{c}R 2=0.4273 \\
(y=2.8906 x+10.695)\end{array}$ & $\begin{array}{c}R 2=0.6141 \\
(y=-0.5979 x+6.0302)\end{array}$ & $\begin{array}{c}R 2=0.9038 \\
(y=-0.5001 x-0.4555)\end{array}$ & $\begin{array}{c}R 2=0.649 \\
(y=0.3682 x+2.2249)\end{array}$ & $\begin{array}{c}R 2=0.6523 \\
(y=-6.2391 x+107.16)\end{array}$ \\
\hline ТPC & $\begin{array}{c}R 2=0.6485 \\
(y=-1.5199 x+38.567)\end{array}$ & $\begin{array}{c}R 2=0.642 \\
(y=0.7261 x-3.609)\end{array}$ & $\begin{array}{c}R 2=0.8736 \\
(y=0.746 x-9.5844)\end{array}$ & $\begin{array}{c}\mathrm{R} 2=0.6582 \\
(\mathrm{y}=-0.1583 \mathrm{x}+5.5111)\end{array}$ & $\begin{array}{c}R 2=0.6446 \\
(y=1.4857 x+56.899)\end{array}$ \\
\hline Yeast \& mold & $\begin{array}{c}R 2=0.5995 \\
(y=2.7226 x+39.181)\end{array}$ & $\begin{array}{c}R 2=0.8216 \\
(y=0.4882 x+0.3074)\end{array}$ & $\begin{array}{c}R 2=0.9105 \\
(y=0.344 x-4.9245)\end{array}$ & $\begin{array}{c}R 2=0.5706 \\
(y=-0.2745 x+5.5356)\end{array}$ & $\begin{array}{c}R 2=0.5955 \\
(y=2.6603 x+56.303)\end{array}$ \\
\hline LAB & $\begin{array}{c}R 2=0.6473 \\
(y=-1.2407 x+36.329)\end{array}$ & $\begin{array}{c}\mathrm{R} 2=0.828 \\
(\mathrm{y}=1.827 \mathrm{x}-13.367)\end{array}$ & $\begin{array}{c}\mathrm{R} 2=0.9315 \\
(\mathrm{y}=1.3924 \mathrm{x}-15.449)\end{array}$ & $\begin{array}{c}R 2=0.6606 \\
(y=-0.1226 x+5.2682)\end{array}$ & $\begin{array}{c}R 2=0.6438 \\
(y=1.2132 x+59.084)\end{array}$ \\
\hline
\end{tabular}



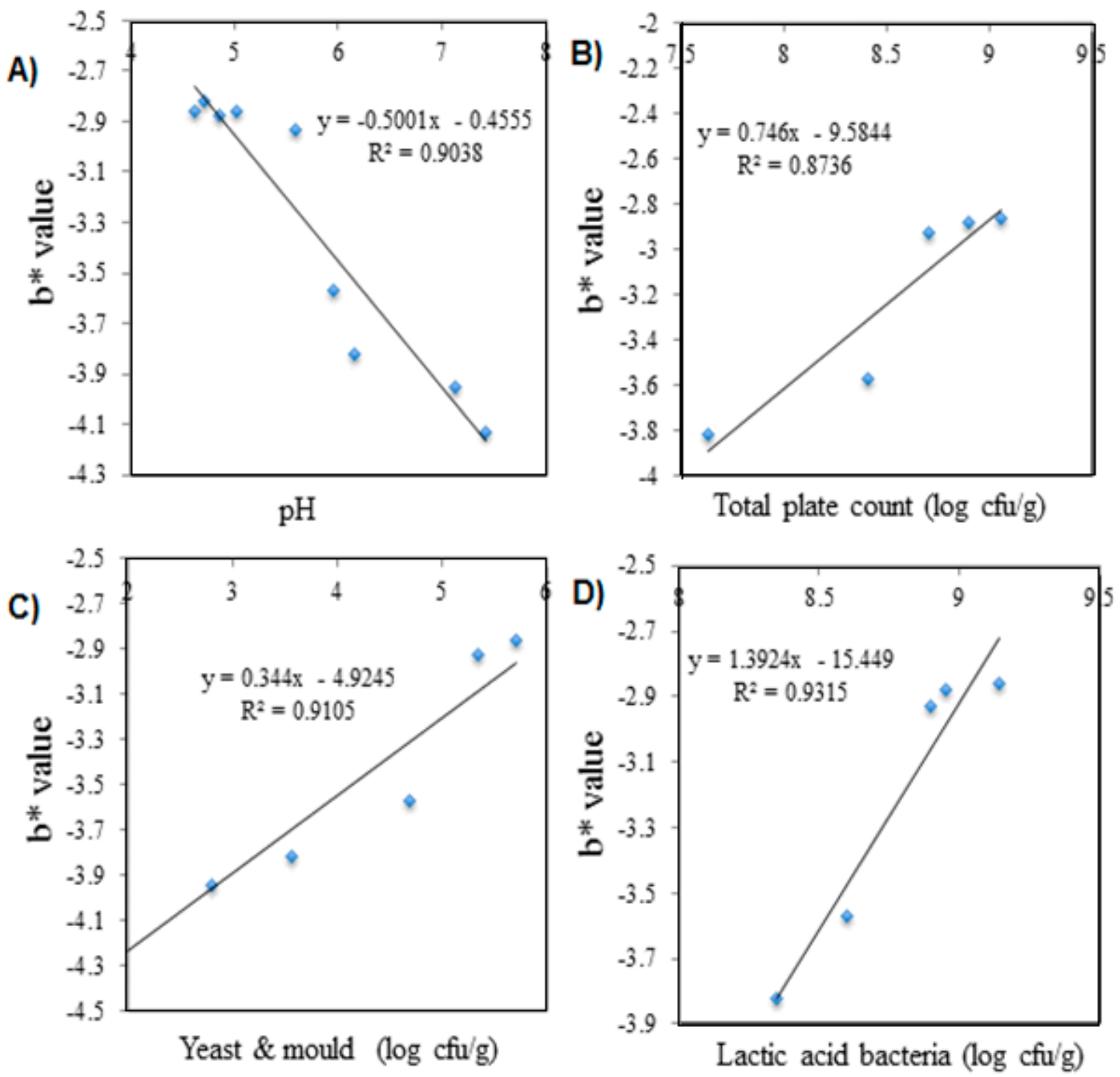

Figure 7. Correlation between $\mathrm{b}^{*}$ value of colorimetric $\mathrm{pH}$ sensor film and parameter analysis of durian samples-(A) pH value; (B) Total plate count-(C) Yeast \& mold counts; (D) Lactic acid bacteria counts (LAB).

\section{Conclusions}

In this study, colorimetric $\mathrm{pH}$ sensor film containing anthocyanin was developed by incorporating mixed natural dyes extracted from Brassica sp and Clitoria sp, using ı-carrageenan as immobilization platform. This colorimetric sensor was developed for the purpose of monitoring food spoilage shows the distinct color changing in ranged of $\mathrm{pH}$ between 1.0 to 10 in studied buffer solution. The ability of the developed colorimetric $\mathrm{pH}$ sensor film to shows color changes on shrimp and durian sample provides a simple way to express the quality of food could offer an efficient alternative approach for monitoring spoilage degree of food samples with potential for the development of intelligent packaging giving direct information on food quality. In future, the proposed colorimetric $\mathrm{pH}$ sensor film could be used along with colorimetric readout that function as a sensor that quickly responds and enabling customers to make decisions easily.

Author Contributions: Idea design, synthesis and characterization, analysis of the data and writing original manuscript, N.A.A.; Project administration and references, L.Y.H. and F.S.; Review \& Editing, M.H.M.Z. and S.A.H. All authors read and approved the final manuscript. 
Funding: This research is supported by the Malaysian Agricultural Research Institute (MARDI) and Universiti Kebangsaan Malaysia (UKM) via funding GP-005179-2016 and MI-2019-010.

Acknowledgments: N.A.A. take this opportunity to thank all of MARDI staff for the support given to completed this study.

Conflicts of Interest: The authors declare no conflict of interest.

\section{References}

1. Rawat, S. Food Spoilage: Microorganisms and their prevention. Asian J. Plant Sci. Res. 2015, 5, 47-56.

2. Nopwinyuwong, A.; Trevanich, S.; Suppakul, P. Development of a novel colorimetric indicator label for monitoring freshness of intermediate-moisture dessert spoilage. Talanta 2010, 81, 1126-1132. [CrossRef] [PubMed]

3. Fung, F.; Wang, H.S.; Menone, S. Food safety in the 21st century. Biomed. J. 2018, 41, 88-95. [CrossRef] [PubMed]

4. Lehotay, S.J.; Hajslova, J. Application of gas chromatography in food analysis. Trends Anal. Chem. 2002, 21, 686-697. [CrossRef]

5. Wang, X.; Wang, S.; Cai, Z. The latest developments and applications of mass spectrometry in food-safety and quality analysis. Trends Anal. Chem. 2013, 52, 170-185. [CrossRef]

6. Qu, J.H.; Liu, D.; Cheng, J.H.; Sun, D.W.; Ma, J.; Pu, H.; Zeng, X.A. Applications of near-infrared spectroscopy in food safety evaluation and control: A review of recent research advances. Crit. Rev. Food Sci. Nutr. 2015, 55, 1939-1954. [CrossRef]

7. Feng, Y.Z.; Sun, D.W. Application of hyperspectral imaging in food safety inspection and control: A review. Crit. Rev. Food Sci. Nutr. 2012, 52, 1039-1058. [CrossRef]

8. Dainty, R. Chemical/biochemical detection of spoilage. Int. J. Food Microbiol. 1996, 33, 19-33. [CrossRef]

9. Wu, D.; Sun, D.W. Colour measurements by computer vision for food quality control-A Review. Trends Food Sci. Technol. 2012, 29, 5-20. [CrossRef]

10. Kerry, M.N.; O'Grady, S.A. Hogan, Past, current and potential utilization of active and intelligent packaging systems for meat and muscle-based products: A review. Meat Sci. 2006, 74, 113-130. [CrossRef]

11. Papadakis, S.E.; Abdul-Malek, S.; Kamdem, R.E.; Yam, K.L. A versatile and inexpensive technique for measuring color of foods. Food Tech. 2000, 54, 48-51.

12. Ibrahim, U.K.; Muhammad, I.I.; Salleh, R.M. The Effect of $\mathrm{pH}$ on Color Behavior of Brassica oleracea Anthocyanin. J. Appl. Sci. 2011, 11, 2406-2410.

13. Smolander, M. The use of freshness indicators in packaging. In Novel Food Packaging Techniques; Ahvenainen, R., Ed.; Wood head Publishing Ltd.: Cambridge, UK, 2003; pp. 128-143.

14. Amit, S.K.; Uddin, M.M.; Rahman, R.; Islam, S.M.R.; Khan, M.S. A review on mechanisms and commercial aspects of food preservation and processing. Agric. Food Secur. 2017, 6, 51. [CrossRef]

15. Saranraj, P.; Geetha, M. Microbial Spoilage of Bakery Products and Its Control by Preservatives. J. Pharm. Biol. Arch. 2012, 3, 38-48.

16. Halagarda, M.; Kędzior, W.; Ewa, P. Nutritional Value and Potential Chemical Food Safety Hazards of Selected Traditional and Conventional Pork Hams from Poland. J. Food Qual. 2017, 2017, 9037016. [CrossRef]

17. El-Ashgar, N.M.; El-Basioni, A.I.; El-Nahhal, I.M.; Zourob, S.M.; El-Agez, T.M.; Taya, S.A. Sol-Gel Thin Films Immobilized with Bromocresol Purple pH-Sensitive Indicator in Presence of Surfactants. Anal. Chem. 2012, 60438911. [CrossRef]

18. Kuswandi, B.; Oktaviana, J.R.; Abdullah, A.; Heng, L.Y. A novel on-package sticker sensor based on methyl red for real-time monitoring of broiler chicken cut freshness. Packag. Technol. Sci. 2014, 27, 69-81. [CrossRef]

19. Shukla, V.; Kandeepan, G.; Vishnuraj, M.R. Development of on package indicator sensor for real-time monitoring of meat quality. Vet. World 2015, 8, 393-397. [CrossRef]

20. Zaggout, F.R. Entrapment of phenol red pH indicator into a sol-gel matrix. Mater. Lett. 2006, 60, 1026-1030. [CrossRef]

21. Turturica, M.; Oancea, A.M.; Rapeanu, G. Anthocyanins: Naturally occurring fruit pigments with functional properties. Ann. Univ. Dunarea Galati Fascicle VI Food Technol. 2015, 39, 9-24.

22. Ferreira, A.R.V.; Alves, V.D.; Coelhoso, I.M. Polysaccharide-Based Membranes in Food Packaging Applications. Membranes 2016, 6, 22. [CrossRef] [PubMed] 
23. Khoo, H.E.; Azlan, A.; Tang, S.T.; Lim, S.M. Anthocyanidins and anthocyanins: Colored pigments as food, pharmaceutical ingredients, and the potential health benefits. Food Nutr. Res. 2017, 61, 1361779. [CrossRef] [PubMed]

24. Shamina, A.; Shiva, K.N.; Parthasarathy, V.A. Food colours of plant origin; review, CAB Reviews: Perspectives in Agriculture, Veterinary Science. Nutr. Nat. Resour. 2007, 2, 87.

25. Giusti, M.M.; Wrolstad, R.E. Acylated anthocyanins from ediblesources and their applications in food systems. Biochem. Eng. J. 2003, 14, 217-225. [CrossRef]

26. Rizk, E.M.; Azouz, A.; Lobna, A.M.H. Evaluation of red cabbage anthocyanin pigments and its potential uses as antioxidant and natural food colorants. Arab Univ. J. Agric. Sci. 2009, 17, 361-372.

27. Kazuma, K.; Noda, N.; Suzuki, M. Flavonoid composition related to petal color in different lines of Clitoria ternatea. Phytochemistry 2003, 64, 1133-1139. [CrossRef]

28. Santos, P.V.; Ditchfield, C.; Tadini, C.C. Development and evaluation of a novel pH indicator biodegradable film based on cassava starch. J. Appl. Polym. Sci. 2011, 120, 1069-1079. [CrossRef]

29. Majdinasab, M.; Hosseini, S.M.H.; Sepidname, M.; Negahdarifar, M.; Li, P. Development of a novel colorimetric sensor based on alginate beads for monitoring rainbow trout spoilage. J. Food Sci. Technol. 2018, 55, 1695-1704. [CrossRef]

30. Hsieh, S.H.; Shen, M.Y.; Huang, Y.S.; He, Q.Q.; Chen, H.C. Mechanical Properties of Glass Bead-Modified Polymer composite. Polym. Polym. Compos. 2018, 26, 35-44. [CrossRef]

31. Ali, A.; Ahmed, S. Recent Advances in Edible Polymer Based Hydrogels as a sustainable Alternative to Conventional Polymers. J. Agric. Food Chem. 2018, 66, 6940-6967. [CrossRef]

32. Zhang, X.; Lu, S.; Chen, X. A visual pH sensing film using natural dyes from Bauhinia blakeana Dunn. Sens. Actuators B Chem. 2014, 198, 268-273. [CrossRef]

33. El-Nahhal, I.M. Entrapment of phenol red (PR) $\mathrm{pH}$ indicator into sol-gel matrix in presence of some surfactants. J. Sol-Gel Sci. Technol. 2015, 75, 313-322. [CrossRef]

34. Chauhan, P.S.; Saxena, A. Bacterial carrageenases: An overview of production and biotechnological applications. 3 Biotech 2016, 6, 146. [CrossRef] [PubMed]

35. Kungsuwan, K.; Sing, K.; Phetkao, S.; Utama-ang, N. Effect of pH and anthocyanin concentration on colour and antioxidant activity of Clitoria ternatea extract. Food Appl. Biol. J. 2014, 2, 31-46.

36. Devarayan, K.; Kim, B.S. Reversible and universal pH sensing cellulose nanofibers for health monitor. Sens. Actuators B Chem. 2015, 209, 281-286. [CrossRef]

37. Schanda, J. Colorimetry: Understanding the CIE System; John Wiley and Sons: Hoboken, NJ, USA, $2007 ;$ p. 467.

38. Anshika, A.; Anant, R.; Natarajan, T.S.; Chandra, T.S. Development of universal pH sensing electrospun nanofibers. Sens. Actuators B Chem. 2012, 161, 1097-1101.

39. Sutee, W.; Chaluntorn, V.; Tanachai, P.; Parichart, T.; Yuthana, P. Kinetics and nondestructive measurement of total volatile basic nitrogen and thiobarbituric acid-relative substances in chilled Tabtim fish fillets using Near Infrared Spectroscopy (NIRS). J. Int. Food Eng. 2016, 2, 16-20.

40. International Commission on Microbiological Specification for Foods (ICMSF). Microorganisms in Food. 4. Application of Hazard Analysis Critical Control Points (HACCP) System to Ensure Microbiological Safety and Quality; Block-well Scientific Publication: Oxford/London, UK, 1978.

41. Gomez, K.A.; Gomez, A.A. Statistical Procedures for Agricultural Research, 2nd ed.; Wiley: New York, NY, USA, 1984.

42. Baublis, A.; Spomer, A.; Berber-Jimenez, M.D. Anthocyanin pigments: Comparison of extract stability. J. Food Sci. 1994, 59, 1219-1221. [CrossRef]

43. Kazuma, K.; Kogawa, K.; Noda, N.; Kato, N.; Suzuki, M. Identification of delphinidin 3-O-(6"-O-malonyl)-beta-glucoside-3'-O-beta-glucoside, a postulated intermediate in the biosynthesis of ternatin C5 in the blue petals of Clitoria ternatea (butterfly pea). Chem. Biodivers. 2004, 1, 1762-1770. [CrossRef]

44. Wiczkowski, W.; Szawara-Nowak, D.; Topolska, J. Red cabbage antocyanins: Profile, isolation, identification and antioxidant activity. Food Res. Int. 2013, 51, 303-309. [CrossRef]

45. Dyrby, M.; Westergaard, N.; Stapelfeldt, H. Light and heat sensitivity of red cabbage extract in soft drink model systems. Food Chem. 2001, 72, 431-437. [CrossRef]

46. Asen, S.; Stewart, R.N.; Norris, K.H. Co-pigmentation of anthocyanins in plant tissues and its effect on color. Phytochemistry 1972, 11, 1139-1144. [CrossRef] 
47. Bkowska, A.; Kucharska, A.Z.; Oszmianski, J. The effects of heating, UV irradiation, and storage on stability of the anthocyanin-polyphenol copigment complex. Food Chem. 2003, 81, 349-355. [CrossRef]

48. Ma, Q.; Wang, L. Preparation of a visual $\mathrm{pH}$-sensing film based on tara gum incorporating cellulose and extracts from grape skins. Sens. Actuators B Chem. 2016, 235, 401-407. [CrossRef]

49. Montilla, C.; Arzaba, M.R.; Hillebrand, S.; Winterhalter, P. Anthocyanin composition of black carrot (Daucus carota ssp. sativus var. atrorubens Alef.) cultivars Antonina, Beta Sweet, Deep Purple and Purple Haze. J. Agric. Food Chem. 2001, 59, 3385-3390. [CrossRef] [PubMed]

50. Rakic, V.P.; Skrt, M.A.; Miljkovic, M.N.; Kostic, D.A.; Sokolovic, D.T.; Ulri, N.E.P. Effects of pH on the stability of Cyanidin and Cyanidin 3-O- $\beta$-glucopyranoside in aqueous solution. Chem. Ind. 2015, 69, 511-522. [CrossRef]

51. Oliveira, J.; Freitas, V.D.; Silva, A.M.S.; Mateus, N. Reaction between Hydroxycinnamic Acids and Anthocyanin-Pyruvic Acid Adducts Yielding New Portisins. J. Agric. Food Chem. 2007, 55, 6349-6356. [CrossRef]

52. Voon, Y.Y.; Sheikh Abdul Hamid, N.; Rusul, G.; Osman, A.; Quek, S.Y. Physicochemical, microbial and sensory changes of minimally processed durian (Durio zibethinus cv. D24) during storage at 4 and $28{ }^{\circ} \mathrm{C}$. Postharvest Biol. Technol. 2006, 42, 168-175. [CrossRef]

(C) 2019 by the authors. Licensee MDPI, Basel, Switzerland. This article is an open access article distributed under the terms and conditions of the Creative Commons Attribution (CC BY) license (http://creativecommons.org/licenses/by/4.0/). 